\title{
Climate Change and Caribbean Small Island States: The State of Play
}

\author{
Lisa Benjamin ${ }^{1}$ \\ The College of The Bahamas
}

ABSTRACT

Studies have indicated that climate change is likely to have dramatic negative effects for Caribbean small island developing states (SIDS). This article considers some of the main economic effects that climate change is anticipated to have in these vulnerable states, charts the progress of international negotiations at the 2009 Copenhagen conference, and provides a brief analysis of the impact of the Copenhagen Accord to Caribbean SIDS.

Although climate change has traditionally been seen solely as an environmental issue, its economic effects on vulnerable developing nations, such as Caribbean SIDS, force a redefinition of climate change to suggest a more complex union of environmental and developmental issues for these states. By highlighting some of the anticipated economic effects of climate change for Caribbean SIDS, the author aims to place this issue into a broader context.

\section{INTRODUCTION}

Climate change poses difficult issues in the international arena. It is a long-term problem which requires coordinated and long-term policy solutions from sovereign states. It is a global problem affecting a global common good, created, in large part, by a number of industrialised nations. Moreover, the effects of climate change will be felt mostly by developing countries including small island developing states (SIDS), which must rely on the largely voluntary future mitigation commitments of certain industrialised countries (Haites, Pantin, Attza, Bruce, \& MacKinnon, 2002, p. 2). These commitments are currently being negotiated through the United Nations Framework Convention on Climate Change (UNFCCC) process, which produced a poor result for Caribbean states in the Copenhagen Accord developed during the $15^{\text {th }}$
Conference of the Parties in Denmark in December 2009.

This article considers some of the main economic effects that climate change is anticipated to have in these vulnerable states, charts the progress of international negotiations at the 2009 Copenhagen conference, and provides a brief analysis of the impact of the Copenhagen Accord to Caribbean small island states.

This commentary on the anticipated economic effects of climate change on Caribbean SIDS draws largely from three major reports: Haites et al. (2002), Assessment of the Economic Impact of Climate Change on CARICOM Countries, Bueno, Herzfeld, Stanton \& Ackerman (2008), The Caribbean and Climate Change: The Costs of Inaction and the Intergovernmental Panel on Climate Change (IPCC) Climate Change 2007: Synthesis Report (2008).

\footnotetext{
${ }^{1}$ Lisa Benjamin, Lecturer, College of The Bahamas/University of the West Indies Law Programme, The College of The Bahamas, P.O. Box N-4912, Nassau, Bahamas.

Acknowledgments: The author is a member of the Bahamas National Committee on Climate Change and The College of The Bahamas Small Island Sustainability programme committee.

E-mail: Ibenjamin@cob.edu.bs

How to cite this article in APA (7 th ed.) style: Benjamin, L. (2010). Climate change and Caribbean small island states: The state of play. The International Journal of Bahamian Studies, 16, 78-91. https://doi.org/10.15362/ijbs.v16i0.129
}

(c) L. Benjamin, 2010. Journal compilation @ The International Journal of Bahamian Studies, 2010. 


\section{A Complex Issue}

Climate change involves both material and, arguably, moral dimensions (Hovi, Sprinz \& Underdal, 2009, p. 28), and is anticipated to have detrimental environmental, social and economic effects for vulnerable developing nations, many of which have not contributed significantly to global greenhouse gas emissions. Climate change, however, is an extremely difficult issue to resolve internationally. As Tol (2009) describes it, "Climate change is the mother of all externalities: larger, more complex, and more uncertain than any other environmental problem" (p. 29). Nation states, marked by territorial sovereignty, many by term-limited governments and market-driven economies, are largely ill-equipped to deal effectively with the problem of climate change (Hovi et al., 2009, p. 29).

Moreover, as efforts to tackle climate change are designed to protect a collective good, some states (particularly those that may be locked into fossil fuel intensive economies who can afford to adapt to the effects of climate change) may be reluctant to cut their emissions unless their economic competitors do the same. This leaves vulnerable states, like those in the Caribbean, in an unenviable position: poised to bear the brunt of the effects of climate change, and largely powerless to mitigate its effects.

\section{Characteristic Vulnerabilities of Caribbean SIDS}

There is no universal definition of Small Island Developing States (SIDS); however, there are currently 51 SIDS included in the list used by the United Nations Department of Economic and Social Affairs. They are categorized by their three regions: AIMS (Africa, Indian Ocean, Mediterranean and South China Sea), the Caribbean, and the Pacific (United Nations Environment Programme [UNEP], 2008, p. 3). Caribbean countries are located between latitudes $11^{\circ}$ and $18^{\circ}$ north, from The Bahamas in the north to Suriname in the south, and, with a few exceptions, consist primarily of island states (p. 6). The Bahamas has been included as it is a member of CARICOM. The Caribbean nonisland states are Belize in Central America and Guyana and Suriname in South America.
Caribbean states are diverse in their governance systems, income, size, topography and political affiliations (UNEP, 2009, p.15). A United States Agency for International Development (USAID) study found the total population in the Caribbean to be approximately 30.3 million, with an overall urban population of 18 million at mid-year 2007 (p. 7). In 2006, the GDP per capita in the Caribbean averaged US\$10,194 (p. 6). In most of these countries there is a general trend towards declining agriculture production and rising service sectors, with tourism providing an average of 35\% of GDP (UNEP, 2009, p. 11). Levels of poverty have been measured at approximately $38 \%$ of the total population according to the United Nations Economic Commission for Latin America and the Caribbean (ECLAC, 2006, p. 5), with levels ranging from between, for example, $9 \%$ in The Bahamas to $75 \%$ in Haiti (p. 4). The study estimated that approximately 6.7 million people in the Caribbean are undernourished (p. 16). ${ }^{2}$

The Caribbean claims high levels of biological diversity, with high levels of endemism and high extinction rates due to unsustainable natural resource exploitation, poorly managed tourism, pollution, habitat destruction, natural events and the introduction of alien species (UNEP, 2009, p. 2). According to USAID, a select group of Caribbean countries scored a total environmental performance index of 72.9, with biodiversity and habitat scoring lowest at 46.7 (2007, p. 34). ${ }^{3}$

Caribbean small island states share a set of common characteristics which make them uniquely vulnerable to the anticipated effects of climate change. One set of common

\footnotetext{
${ }^{2}$ Poverty was defined as a lack of economic resources or an absence of living conditions considered basic by the society. Levels of extreme poverty were not available for this study and statistical data was scarce for the statistics on undernourishment (UN ECLAC, 2009, p. 7 and p. 16) ${ }^{3}$ USAID provided an environmental index for a select group of Caribbean countries measuring the broad environmental protection objectives of reducing environmental stresses on human health, and promoting ecosystem vitality and sound natural resource management. The study scored countries on a scale of 0-100, with higher scores being better.
} 
characteristics are geographic vulnerabilities, which include:

- low-lying areas vulnerable to sea level rise and storm surges;

- geographic positions strongly affected by tropical storms and hurricanes;

- current high temperatures (e.g., with mean annual values of $20^{\circ} \mathrm{C}$ and above; Haites et al., 2002, p. 5);

- scarce land resources; and

- considerable dependence on fresh groundwater resources.

These geographic characteristics are compounded by socio-economic vulnerabilities, including:

- concentrations of population and infrastructure along coastal regions. It is estimated that approximately $70 \%$ of the Caribbean population lives in coastal cities, towns and villages (UNEP, 2008, p. 7);

- dependence on a narrow range of export products;

- susceptibility to international trade and commodity prices;

- $\quad$ small domestic markets and limited ability to develop economies of scale;

- limited opportunities for economic diversification;

- high transportation and communication costs; and

- weak institutional structures and limited human capacity (UNEP, 2008, p. 3).

Combined, these characteristics make Caribbean SIDS uniquely vulnerable to the environmental impacts of climate change, and their attendant social and economic effects.

\section{Economic Effects of Climate Change}

Greenhouse gases are defined as gaseous constituents that absorb and re-emit infrared radiation (UNFCCC, 1992, Article 1.5) and commonly include carbon dioxide, methane, nitrous oxide, hydrofluorocarbons, perfluorocarbons and sulphur hexafluoride. Once emitted, these gases remain in the atmosphere for long periods of time. The IPCC's Climate Change 2007: Synthesis Report (2008) stated that both past and future anthropogenic $\mathrm{CO}_{2}$ emissions will continue to contribute to global warming and sea level rise for more than a millennium due to the time scales required for the removal of this gas from the atmosphere (p. 47) ${ }^{4}$. As such, climate change will continue for some time because of past emissions, even if greenhouse gas emissions were to be stabilized today.

A major international study on the economic effects of climate change was prepared by Stern (2006) for the British Government. Stern states that "Climate change is a result of the externality associated with greenhouse-gas emissions - it entails costs that are not paid for by those who create the emissions” (p. 23). As a result, it can be seen as market failure of the greatest scale, and entails four interconnected complexities:

- it is a global externality in cause and consequence;

- its impacts are persistent and develop over time;

- the uncertainties surrounding climate change are considerable both about its potential, size, type and timing of its impacts, and the costs of combating it; and

- its impacts are likely to have significant effects on the global economy (p. 25).

In addition, Stern states that the effects of climate change will not be felt evenly across the globe, allowing some countries to benefit from modest increases in temperature, and others to suffer. At greater temperature increases, most countries will suffer heavily as global growth is adversely affected (2006, p. 55). All developmental aspirations of states could be affected by climate change (p. 114). Coupled with population growth, climate change could lead to slower growth leading to increasing levels of poverty, which may in turn exacerbate competition for

\footnotetext{
${ }^{4}$ The World Meteorological Organization (WMO) and the United Nations Environment Programme (UNEP) established the IPCC in 1988.

Membership is open to member states of the WMO and UNEP. The IPCC represents a unique partnership between the scientific community and governments. Its role is to provide policy-relevant but not policy-prescriptive information on key aspects of climate change, including the physical basis, and impacts of and vulnerability to climate change in human and natural systems.
} 
resources, and potentially lead to dislocation, migration and even conflict (p. 108-112).

Stern estimated the total cost of business as usual climate change over the next two centuries will equate to an average welfare loss equivalent to at least $5 \%$ of the value of the global per capita consumption now and forever (2006, p. 144). If impacts on health and the environment, including the disproportionate burden on poor regions of the world, are taken into account, the costs could accumulate to around $20 \%$ (p. 144). It is important to note that the economic modelling used in the Review to quantify the potential economic effects of climate change are for illustrative purposes only, and contain large values of uncertainties. However, in all the scenarios used, the consequence of climate change is anticipated to become disproportionately more severe with increased warming (p. 158). Stern also calculated that the costs of action to reduce greenhouse gases enough to avoid the worst impacts of climate change, could be limited to as little as 1\% of global GDP (2006, p. 572).

Tol (2009) provides an analysis of previous studies of the anticipated global economic impacts of climate change and various models used over the years (p. 30-33). As with the Stern Review, Tol's comparison of previous studies shows that some regions will be negatively affected by climate change, and some may benefit from modest increases in temperatures, although the analysis suggests that the turning point in terms of economic benefits occurs at $1.1^{\circ} \mathrm{C}$ (p. 34). The study leads to two policy conclusions. First that any stringent abatement of greenhouse gases from industrialised countries involves in part a consideration of the plight of citizens of lowincome countries and the effects imposed on them by citizens of high-income countries and second, "if pre-existing poverty is one of the main causes for vulnerability to climate change, one may wonder whether stimulating economic growth or emission abatement is the better way to reduce the effects of climate change" (p. 36).

Both Tol and Stern point to the vast levels of uncertainties involved in estimating the economic effects of climate change. Both also point out that negative surprises are more likely than positive ones (Tol, 2009, p. 37; Stern, 2006, p. 291), thereby providing impetus to global efforts to address the issue.

\section{Economic Effects of Climate Change on Small Island States}

There is a limited amount of research on the economic effects of climate change on small island states in the Caribbean. Both Haites et al. (2002) and Bueno et al. (2008) state that they were hampered by the lack of availability of comprehensive data in the Caribbean.

The Haites et al. study estimated that the largest category of impacts in the Caribbean due to climate change would be the loss of land, tourism infrastructure, housing and other infrastructure due to sea level rise (an estimated $65-75 \%$ of the total losses; 2002, p. 44). The remaining losses would be due to reduced tourism demand because of increased temperatures, loss of beaches, coral reefs and other ecosystems (15-20\% of the losses), as well as property damage as a result of increased intensity of hurricanes and tropical storms (7-11\% of the losses; Haites et al., 2002, p. 44). The report estimated a potential economic range of impact of US\$1.4 to $\$ 9$ billion on the 2000 economy. The report itself advocated treating its results with some caution, for several reasons. The wide range of estimates resulted from limited data and numerous assumptions that had to be made about the economic impact of climate change (not due to uncertainty about the occurrence of climate change), and therefore the figures should be treated as very rough estimates (Haites et al., 2002, p. iii). The report based economic impacts on the then current (2000) Gross Domestic Product (GDP) figures, even though climate change may continue to occur for over 50 to 80 years, and future Caribbean GDPs may be less sensitive to climate change. The estimated economic effects did not include adaptation measures which may reduce the potential economic impact of climate change. In addition, the report did not include some anticipated categories of economic loss, such as loss of agricultural and fisheries output, as the values could not be calculated with existing data. Finally, it is important to note that the report was based on the Third Assessment Report of the IPCC published in 2001, however, it provides a useful starting point to target areas for adaptation to climate change in the Caribbean. 
Bueno et al. (2008) based their report on the IPCC's Fourth Assessment Report (summarized in its Climate Change 2007: Synthesis Report, 2008). This report significantly increased the estimated economic damage in the Caribbean. The report compared two scenarios: one high impact scenario, based on business as usual with global emissions going unchecked throughout the 21st century, and a low impact scenario based on rapid global stabilization of greenhouse gas emissions leading to greatly reduced emissions by 2050. The difference between the two scenarios was calculated as the costs to the Caribbean of global inaction on climate change. These costs were estimated at US $\$ 22$ billion annually by 2050 and US\$46 billion annually by 2100 for the Caribbean region; representing $10 \%$ and $22 \%$ of the Caribbean's GDP based on 2004 GDP results (Bueno et al., 2008, p. 2). The results vary by region; for example, in The Bahamas, the estimated costs are $6.6 \%$ of GDP by 2025, rising to $31.7 \%$ of GDP by 2100 (p. 4). These estimates may be conservative, as they were based on only three categories of losses: hurricane damage, tourism losses and infrastructure damage from sea level rise exclusive of hurricane damage. Due to lack of access to data, these estimates did not take into account the effects of climate change on areas such as agriculture, public health, water resources, energy and other ecosystem losses (p. 2). Already, these potential losses are staggering costs for small, fragile economies to bear. As these costs may not be avoidable, it may mean that already limited resources will have to be diverted from other pressing developmental needs such as education and poverty reduction. The report makes sober reading, stating,

As damages mount up, climate change will cause a breakdown in Caribbean economic life; at some point - likely well before the projected annual damages reach $100 \%$ of GDP - it will become impossible to keep restoring damaged property, and tourism and other weathersensitive industries will move elsewhere. Indeed, as sea levels rise, residents of small, low-lying islands like Turks and Caicos, may be unable to continue inhabiting them (pp. 14-15).

\section{Sectoral Impacts}

The IPCC Climate Change 2007: Synthesis Report (2008) states with very high confidence (a term used by the IPCC to assess uncertainty quantitatively meaning a confidence scale of 9 out of 10) that the global average net effect of human activities since 1750 has been one of warming (p. 37). The IPCC (2008) found that during the period 1995-2006, eleven of those twelve years were recorded as the twelve warmest years in global surface temperatures since 1850 (p. 30). Future anticipated warming is estimated by the report based on a number of emission scenarios reported in the IPCC's Special Report on Emissions Scenarios (SRES) published in 2000. Most notably, the A1F1 fossil fuel intensive (or business-as-usual) scenario anticipates an increase of $4{ }^{\circ} \mathrm{C}$ by the end of the century (based on an estimated range of $2.4-6.4{ }^{\circ} \mathrm{C}$ rise; IPCC, 2008, p. 45).

Continued climate change is anticipated to be largely inevitable considering past global emissions and the long-lived effect of greenhouse gases in the atmosphere, and will have a variety of sectoral impacts in the Caribbean. Its effect on the economy and ecosystems of the Caribbean will be particularly devastating for poor communities in the region, who often rely on environmental products and services for subsistence products, income, food security and health (Stern, 2006, p. 95).

\section{The Impact of Temperature Increases on Tourism and Health in the Caribbean}

Haites et al. reported that average annual temperatures in the Caribbean have already risen by at least $0.5^{\circ} \mathrm{C}$ over the period 1900-1995, and in some Caribbean countries by $1^{\circ} \mathrm{C}$ (2002, p. 5). They also estimated future temperature increases in the Caribbean from $1.5-1.9{ }^{\circ} \mathrm{C}$ by 2050 , and from $2-3.3^{\circ} \mathrm{C}$ by 2080 in the warmest months of June through August (2002, p. 7). However, these estimates may be conservative as the report was based on the data published in Climate Change 2001, also known as the Third Assessment Report of the IPCC.

As global temperatures increase, tourists may choose not to travel to tropical destinations, content with warmer local temperatures, and Caribbean temperatures may become too hot for them. Research by Lise and Tol conducted on climate change and tourist demand in Europe found that climate is a very important factor in a 
tourist's choice of destination, with the ideal temperature being $21^{\circ} \mathrm{C}$ (as cited in Haites et al., 2002, p. 26). With the mean average temperature of the northernmost Caribbean Community (CARICOM) country, The Bahamas, already at 23 ${ }^{\circ} \mathrm{C}$ in January and $28{ }^{\circ} \mathrm{C}$ in July (Haites et al., 2002, p. 26), the Caribbean may already be too hot for the majority of European tourists.

Increased temperatures will also allow for an increase in vector-borne diseases, such as malaria and dengue fever, and also acute respiratory infections and heat stress (Haites et al., 2002, p. 39 and UNEP, 2008, p. 19). Increased instances of diseases will put increased strain on already overburdened public health institutions in the region.

\section{Sea Level Rise, Infrastructural and Ecosystem Loss}

The rise in global temperatures causes sea levels to rise because of thermal expansion of water in its natural state, and the melting of glaciers, polar ice caps and polar ice sheets (IPCC, 2008, p. 30). Thermal expansion is estimated to contribute approximately $57 \%$ of sea level rise, with ice cap and glacier melt contributing about $28 \%$ and polar ice sheet melt the remainder. The oceans absorb over $80 \%$ of the heat being added to the climate system, and take longer to warm than land (p. 30). As a result, it is anticipated that sea levels will continue to rise long after (and if) greenhouse gas emissions are stabilized.

The IPCC (2008) stated that global sea levels rose at an average rate of $1.8 \mathrm{~mm}$ per year from 1961 to 2003, with a much greater average rise from 1993 to 2003 of $3.1 \mathrm{~mm}$ per year (p. 30). Using the same emissions scenario of A1F1, the IPCC anticipates that sea levels will rise between 0.26$0.59 \mathrm{~m}$ by the end of the century (p. 45). This estimate is conservative as it excludes uncertainties in climate carbon-cycle feedbacks, and the full effects of future changes in ice sheet flow (p. 45). ${ }^{5}$ Sea level rise rates will vary across the Caribbean region as various factors may affect

\footnotetext{
${ }^{5}$ These results were not included because a basis in published literature for them was lacking. As a result, the upper values for sea level rise given in the IPCC Report are not considered upper bounds for sea level rise, and the rise is expected to be higher than anticipated.
}

it, such as the rate of warming, the efficiency of ocean circulation and local atmospheric effects and currents (Haites et al., 2002, p. 6).

Sea level rise would have catastrophic effects on most Caribbean SIDS, and may even render some islands uninhabitable. For those Caribbean islands that do remain habitable, sea level rise will likely necessitate expensive relocation and rebuilding exercises, as their infrastructure is mainly located in vulnerable coastal areas. Haites et al. (2002) estimate an annualized replacement cost for buildings and infrastructure on land lost to sea level rise at approximately US\$960 million to US\$6.1 billion (p. 32). This will cause immense disruption to economic, social and cultural ways of life in the Caribbean.

Increased sea levels will also lead to coastal erosion and loss of coral reefs, mangroves and other wetland areas. The annual value of beach areas lost due to sea level rise is estimated at between US\$550 million to US\$2.4 billion in the Caribbean due to loss of tourism alone (Haites et al., 2002, p. 29). Burke and Maidens (2004) estimated the annual net economic value of coral reefs in the Caribbean to be between US\$3.1 billion and US $\$ 4.6$ billion as a result of their ecosystem services which provide tourism revenue, high fishery yields, and shoreline protection (p. 14). By 2015 the annual losses due to degradation of coral reefs in the Caribbean are estimated at between US\$100-300 million to the tourism industry (p. 14), although the losses may be disproportionate in one area as tourists move to healthier reef systems.

Stern states that globally, people will feel the impact of climate change most strongly through changes in the distribution of water around the world (2006, p. 62). Countries such as Antigua and Barbuda, The Bahamas, Barbados, and Grenada, will suffer further from sea level rise as they are heavily reliant on groundwater resources and are already deemed to be water-stressed countries (Haites et al., 2002, p. 34). Salt water intrusion into freshwater lenses as a result of sea level rise, combined with over-extraction from these lenses and reduced precipitation, would devastate these important sources of freshwater. The cost to these four water-stressed countries was estimated by the Haites et al. report as 
adaptation costs because the value of existing freshwater sources where water was scarce was not available. The adaptation costs were estimated by calculating the cost differential of producing desalinated water against using surface and groundwater supplies, on the assumption that freshwater supplies will decline by $8 \%$ in these countries. The costs were estimated at US $\$ 4.9$ to US\$8.4 million for these four countries (Haites et al., 2002, pp. 34-35).

Reilly et al. (2007) come to some varying conclusions when comparing, in different scenarios, the combined impact of changes in climate, increases of $\mathrm{CO}_{2}$, and changes in ozone on crops, pasture and forest land productivity. This is a unique study as it looks at the effects of both $\mathrm{CO}_{2}$ and ozone emissions. Changes in climate and $\mathrm{CO}_{2}$ effects alone were found to be beneficial globally in terms of increased yields, however, when combined with ozone damage, many areas experienced severely negative effects, especially cropland areas in the Northern Hemisphere (p. 11). The study acknowledges that the net economic effects of changes in agriculture, pasture and forestry are a complex combination of changing patterns of trade and other resource reallocations (p. 16).

The Caribbean Catastrophe Risk Insurance Facility (2010) estimates that the overall impacts to the agricultural sector in the Caribbean due to climate change will vary dramatically between its countries. Changes in yields will be induced by climate zone shifts, leading to, for example, an estimated negative shift of $45 \%$ in yields for sugar cane in Belize, but a positive 10\% shift in yields for bananas in Belize based on net production volumes of 2030 compared to 2009 (p. 21).

\section{Rising Water Temperatures and Ocean Acidification}

The rise in sea temperature is anticipated to have many detrimental effects on marine and freshwater biological systems, including coral reefs (IPCC, 2008, p. 33). Coral reefs are very sensitive to temperature changes, tolerating only slight increases. They react to elevated water temperatures by paling in colour or bleaching (Haites et al., 2002, p. 12). Hoegh-Guldberg et al. (2007) looked at the combined impact of rapid climate change and ocean acidification on coral reefs, and indicates that temperatures of $1{ }^{\circ} \mathrm{C}$ to 2 ${ }^{\circ} \mathrm{C}$ over the summer maxima for 3 to 4 weeks can lead to coral bleaching (p. 1740). There have already been many coral bleaching events in the Caribbean followed by high levels of coral mortality (UNEP, 2008, p. 8). Recent studies also suggest that $80 \%$ of living coral reefs in the Caribbean have been lost in the past twenty years (p. 7). Human stressors such as anchoring on reefs, dynamiting and applying chemicals for fishing, combined with unabated climate change, could lead to widespread coral mortality throughout the Caribbean (IPCC, 2008, p. 65).

Coral reefs represent important resources for the Caribbean, providing protective barriers for beaches and coasts, and nurseries for fish and crustaceans. They also provide the setting for a significant amount of biodiversity in the Caribbean. However, "the open-access nature and public good characteristics of these resources often results in their being undervalued in decision making regarding their use and conservation" (Brander, Rehdanz, Tol, \& van Beukering, 2009, p. 4). Brander et al.’s results concerning valuation of coral reefs state that, all else being equal, Caribbean reefs have higher values than reefs in any other region studied (2009, p. 6). The loss of these reefs will have a detrimental effect on tourism and fishing industries in the Caribbean, presenting a loss in GDP for seafood exporting nations, as well as a loss of a critical source of dietary protein for subsistence fishermen and poor communities (UNEP, 2008, p. 12). ${ }^{6}$

As the oceans absorb more carbon from the atmosphere, it is anticipated that the oceans will become more acidic. The Brander et al. study indicates that under different IPCC SRES scenarios, estimated global loss of coral reefs due only to projected ocean acidification by the 2100 s varies from $16 \%$ (but falling) in the B1 scenario, to $27 \%$ (but rising) in the A2 scenario (2009, p.7). The study by Hoegh-Gulburg et al. indicates that combined acidification and bleaching enhances the trajectory of coral reefs towards domination by macroalgae and non-coral communities (2009,

\footnotetext{
${ }^{6}$ In the Caribbean, fish is the most important source of protein after poultry (UNEP, 2009, p. 60).
} 
p. 1740). Whilst the effects of ocean acidification are not entirely certain (impact and economic studies are rare), it is anticipated that ocean acidification will impact the future growth of coral reefs and the ability of crustaceans to form shells; a further blow to the tourism and fishing industries and welfare of the Caribbean.

\section{Increased Hurricane Intensity and Storm Surges}

The IPCC stated that it is likely that future tropical cyclones (typhoons and hurricanes), will become more intense, with larger peak wind speeds and heavier precipitation (2008, p. 46). There are few global historical records of tropical cyclones, and this fact, combined with large fluctuations in the frequency and intensity of tropical cyclones, makes any predictions regarding increased frequency and/or intensity of tropical cyclones difficult (Knutson et al., 2010, p. 157). Knutson et al. state that on the basis of projected $21^{\text {st }}$ century global warming, there will be some increase in the mean maximum wind speed of tropical cyclones (e.g., storm intensity) of approximately $2-11 \%$ globally, with increased rainfall rates, but with potential decreases in the overall frequency of tropical cyclones (2010, p. 158-161). Increased intensity of tropical cyclones would lead to increased storm surges and flooding events, causing infrastructural damage, loss of life, increased injuries, an increased spread of vector-borne diseases, and a reduced tourist demand.

These individual sectoral impacts may become even more damaging when combined in a climate feedback loop. For example, the absence of coral reefs acting as natural barriers, combined with increased sea levels, increased intensity of hurricanes, and increased storm surges may have an exponentially negative effect on Caribbean states. Stern states that climate change itself may be a powerful feedback loop which could accelerate future warming (2006, p. 10).

It is clear that the cumulative effects of climate change are likely to have negative implications for the livelihoods of populations in the Caribbean (UNEP, 2008, p. 25), making climate change an urgent problem for the people of the Caribbean. However, recent international negotiations aimed at tackling the issue of climate change have failed to provide adequate measures to fully mitigate the anticipated effects of climate change for Caribbean SIDS.

\section{The Copenhagen Conference}

The Copenhagen Accord was the result of the Copenhagen Conference held December 7-19, 2009. The Conference represented the 15th Conference of the Parties to the UNFCCC since the Convention came into effect in 1994.

The UNFCCC is a framework convention that includes general obligations for its parties, but does not include specific, binding emissions targets. As of December 2009, the UNFCCC had 192 parties (including the United States). The first major protocol agreed under the UNFCCC was the Kyoto Protocol, which came into force in 2005, and by the end of 2009 had 190 parties, with the United States being the only developed country that failed to ratify the Protocol. The Kyoto Protocol includes binding emissions targets for developed country parties. These are listed in Annex I of the Protocol, and developed countries which are subject to these targets are called Annex I Parties. Developing country parties to the Kyoto Protocol have no binding emissions targets, and are therefore referred to as non-Annex I Parties.

International climate change negotiations under the UNFCCC to date have continued along two negotiating tracks: one under the UNFCCC called the Ad Hoc Working Group on Long-term Cooperative Action, and one under the Kyoto Protocol called the Ad Hoc Working Group on Further Commitments for Annex I Parties.

The emissions targets for Annex I Parties under the Kyoto Protocol will expire in 2012. At the 13th Conference of the Parties in Bali, Indonesia, which took place in 2007, parties to the UNFCCC agreed that a second commitment period was necessary for developed countries to reduce their emissions, and that a program of adaptation for developing countries was also needed. This 2007 agreement, called the Bali Roadmap, stated that developing countries would agree to nationally appropriate mitigation actions, which would, however, not be binding. The Bali Roadmap anticipated that these issues would be agreed as part of a binding legal agreement during the Copenhagen Conference in 2009. 
Disappointingly, for various reasons, this did not occur.

\section{The North-South Negotiating Divide ${ }^{7}$}

There has been a growing divide between industrialised (north) and developing (south) countries over the form and content of international climate change obligations.

Many developing countries have seen the issue as one of obligations owed from industrialised countries for the damage that their emissions have caused and will cause to these developing countries, and of an equitable sharing of development space in the future (Dubash, 2009, p. 8). Many vulnerable developing countries expected that climate change negotiations would centre on the principle of international equity, encapsulated in Article 3.1 of the UNFCCC (1992) which states:

The Parties should protect the climate system for the benefit of present and future generations of humankind, on the basis of equity and in accordance with their common but differentiated responsibilities and respective capabilities [emphasis added]. Accordingly, the developed country Parties should take the lead in combating climate change and the adverse effects thereof.

As a result, many developing countries hoped for a legally binding agreement from the Annex I Parties of the Kyoto Protocol and the United States, containing dramatic cuts in emissions from industrialised countries. In particular, the Alliance of Small and Island States, the negotiating bloc for SIDS, expected that pledged emissions cuts would keep the level of temperature rise to $1.5{ }^{\circ} \mathrm{C}$ compared to preindustrial levels, using the slogan " 1.5 to stay alive”. This would have meant that carbon concentrations in the atmosphere would have to be stabilised at roughly $350 \mathrm{ppm}$, necessitating a reduction of existing atmospheric carbon concentration. In 2009 carbon concentrations were already roughly 387 ppm (Vidal, 2009).

\footnotetext{
${ }^{7}$ The negotiating blocs and positions of industrialised and developing countries are complex and vary by issue. This article provides a very general overview of positions.
}

On the whole, following the Bali Roadmap, most developing countries were not expecting to commit to mitigation actions, nor were they expecting their mitigation actions to be subjected to international monitoring, reporting and verification. In particular, developing countries wanted to retain a hard divide between the two negotiating tracks under the UNFCCC (where developing countries were not expected to agree to emissions cuts but were expected to agree to non-binding nationally appropriate mitigation actions) and under the Kyoto Protocol (where developed countries were expected to agree to new and binding emissions cuts). Following the Bali Roadmap, many developing countries wanted new and additional financial assistance from industrialised countries to help them adapt to climate change. It was anticipated by developing countries receiving assistance that they would have control over the disbursement of these funds. This assistance was not anticipated to be structured in the form of a loan, but rather as compensation for an ecological debt owed to developing countries that would not be conditional upon mitigation efforts.

Many industrialised countries, on the other hand, argued that they owed no historic ecological debt to developing countries. It was the United States lead climate negotiator Todd Stern “... who said 'I actually completely reject the notion of a debt or reparations or anything of the like' (Roberts, 2009)” (Brown, 2010, Section 2, para. 24). Adaptation financing was framed by the United States as charity or largesse (Section 2, para. 24), thus effectively withdrawing any obligation to pay. Although the European Union tried to convince industrialised countries to agree to deep emissions cuts, these largely fell on deaf ears (Guérin \& Wemaere, 2009, p. 6). The United States's emissions position never changed in Copenhagen, largely because no United States domestic legislation on climate change had yet been passed (p. 6).

Industrialised countries, in particular the United States, expected binding emissions cuts from emerging developing nations like China and India. Their argument was based, in part at least, on the fact that developing countries will account for over three quarters of the increase in emissions up to 2030 (Stern, 2006, p. 176). Developed 
countries also expected that the mitigation efforts of these developing nations would be subject to international monitoring, reporting and verification. In fact, instead of a debate focusing on the urgent need to cut emissions for the benefit of vulnerable nations such as SIDS, much of the critical negotiations which led to the Accord centred on the relationship between the United States and China.

With negotiations at a standstill, a limited number of heads of states took the unprecedented and contentious step of drafting the Copenhagen Accord, which was only noted by the full Conference of the Parties.

\section{The Copenhagen Accord}

At least 25 countries were asked by the Conference of the Parties President to participate in a high-level meeting in which the Copenhagen Accord was hammered out. However, at the full Conference of the Parties session, the Accord was not adopted, as there was no unanimous agreement for the Parties to do so. At least four countries objected, including the small island state of Tuvalu, and so the Accord was noted, and not adopted, by the Conference of the Parties.

The Accord appears to represent a political bargain between the United States and the BASIC (Brazil, South Africa, India and China) countries. It is arguable that the outcome of the United Nations process in Copenhagen favoured the big and emerging economic powers. As a result, the Copenhagen Accord proved to be a great disappointment for Caribbean SIDS for several reasons:

- the Accord is not a legally binding agreement, and does not anticipate a legally binding agreement being concluded in the next Conference of the Parties in Mexico in 2010 or at any time in the future. This means that emissions cuts provided by the parties under the Accord are not mandatory and cannot be enforced;

- the Accord agrees to reduce global emissions to hold the increase in global temperature below $2{ }^{\circ} \mathrm{C}$, and not the $1.5{ }^{\circ} \mathrm{C}$ that most SIDS consider necessary to prevent dangerous climate change;

- the Accord does not agree to an atmospheric carbon concentration limit, which many believe is necessary to make any temperature limit meaningful;

- the Accord does not include a baseline year for emissions targets, allowing some nations, like the United States and Canada, to make their baseline 2005 instead of the almost universally agreed baseline of 1990 under the Kyoto Protocol;

- $\quad$ the Accord does not limit parties to any peak year for their emissions (the rate of emissions cuts required to meet a stabilisation goal is very sensitive to both the timing of the peak of global emissions and the height of that peak; Stern, 2006, p.199);

- the Accord does agree to reassess its implementation, in particular, limiting temperature rise to $1.5^{\circ} \mathrm{C}$, but not until 2015, a date that many scientists consider too late to stop a $2{ }^{\circ} \mathrm{C}$ rise or greater; and

- the Accord takes a bottom up approach, allowing each individual country to make its own emissions pledges.

There lies within the Accord both cause for limited optimism and great concern. Hope may exist for SIDS in the promise of a commitment of financial resources from developed countries, “approaching USD 30 billion” (UNFCCC, 2010, Article 8) for 2010-2012, prioritized for the most vulnerable nations, including SIDS, with a goal of mobilizing US $\$ 100$ billion dollars a year by 2020 (Article 8). However, no financial institution or governance mechanism has been agreed for these funds, although the Copenhagen Green Climate Fund has been proposed to administer a significant portion of the funding, with a governance mechanism that equally represents both developed and developing countries (Article 8).

The major cause for concern for SIDS in the Accord is the $2{ }^{\circ} \mathrm{C}$ temperature goal. There is a real danger that the $2{ }^{\circ} \mathrm{C}$ agreement in the Accord will remain unchanged in the next Conference of the Parties in Mexico at the end of 2010. Carlos Fuller, Deputy Director of the Caribbean Centre for Climate Change, stated that the work of 16th Conference of the Parties in Mexico “... could be limited to merely translating the Copenhagen language into a new international agreement” (2010, p. 5). 
The UNEP (2008) report stated that:

For SIDS, the goal of stabilizing temperatures at $2{ }^{\circ} \mathrm{C}$ above pre-industrial levels fails to consider the survival of island states, and means the loss of many critical ecosystems, including coral reef and fisheries, the flood of coastal communities, stronger storms, reduced water supply, increased droughts and desertification, and threats to food security (p. 75).

However, a new report estimates that the emissions pledges that the industrialized and seven non-Annex I Parties have already committed to under the Accord are not sufficient to meet even the $2{ }^{\circ} \mathrm{C}$ temperature goal (Den Elzen, et al., 2010, p. 49).

Stern reports that little can be done to change the predicted impacts of the existing stocks of atmospheric greenhouse gases on developing countries in the next few decades, and some adaptation will therefore be essential (2006, p. 92). Stern also contends that there are strong complementarities between development policy and adaptation actions in highly vulnerable states (2006, p. 305).

Despite disappointing international efforts on mitigation, SIDS do have access to funding and are able to carry out adaptation projects both in the immediate future, and over the next few decades. Many of the studies discussed in this article do not incorporate the potential that adaptation has to significantly decrease the costs of climate change to the Caribbean. While coordinated global mitigation efforts rely to a large extent on international co-operation, adaptation efforts do not. Adaptation efforts can be based on international financing, bilateral, or even regional co-operation, and can deliver direct, local benefits to the region.

Regional adaptation measures could include improved environmental management policies and practices, such as comprehensive land and coastal development policies and practices, sustainable fishery yields and strategically placed marine protected areas. Combined these could help strengthen the resilience of fisheries, coral reefs and coastal zones. Such efforts should be combined with public education and outreach strategies to raise awareness of the value of natural ecosystems.

\section{CONCLUSION}

Although climate change poses difficult issues internationally, the unique characteristics of Caribbean SIDS make them especially vulnerable to a changing climate. The anticipated economic costs of climate change for small, fragile Caribbean economies, combined with significant ecosystem impacts, propels the issue of climate change for Caribbean SIDS from an environmental issue to a critical environmental and developmental issue.

The unique vulnerability of Caribbean states to the effects of climate change stands in stark relief to their responsibility for the same. The Haites et al. study estimated that CARICOM countries are responsible for only $0.16 \%$ of global $\mathrm{CO} 2$ emissions (2002, p. 2). However, climate change will have a disproportionate effect on vulnerable Caribbean states, and an even greater effect on the poor of those states.

Strong and early mitigation is the only way to avoid some of the more severe impacts that could occur in the second half of this century (Stern, 2006, p. 91). Considering the vulnerable position of Caribbean SIDS, and the dubious results for SIDS that the last international round of negotiations produced in the Copenhagen Accord, it would appear incumbent upon SIDS to continue to demand a renegotiation of the $2{ }^{\circ} \mathrm{C}$ temperature goal. It is critical for SIDS that industrialized countries and large developing countries agree to further reduce their own emissions. The difficulty for SIDS in this regard is that they have nothing to offer industrialised countries "no cash to offer and minimal emissions to reduce” (Huq, Chandani, \& Anderson, 2009, p. 1).

The way forward for Caribbean SIDS is challenging, and will involve complex policy choices. Well managed domestic growth and development can help to equip SIDS to better manage climate change, not just as an environmental issue, but as a developmental issue as well. Given the potentially heavy costs of climate change for the region, mitigation and adaptation strategies must form part of integrated national developmental and budgetary plans, preferably spearheaded by a central ministry such 
as the Ministry of Finance to ensure priority and implementation.

Future negotiations at the 16th UNFCCC Conference of the Parties in Cancun, Mexico from November 29-December 10, 2010 and the United Nations Conference on Sustainable Development in Rio de Janeiro, Brazil (or Rio +20) in 2012, will become key platforms for Caribbean SIDS to raise awareness of the developmental impact of climate change on their states.

\section{Postscript}

After this article was written, a report by the Netherlands Environmental Assessment Agency (PBL, 2010) was published. The PBL report consisted of a review of the IPCC Working Group II's regional chapter and summary conclusions. The IPCC's Fourth Assessment Report consists of four volumes published with the umbrella title Climate Change 2007: The Physical Science Basis, contribution of Working Group I; Impacts, Adaptation and Vulnerability, contribution of Working Group II; Mitigation of Climate Change, contribution of Working Group III; and a Synthesis Report which integrates the main outcomes of the three Working Group reports. As the IPCC Climate Change 2007: Synthesis Report (2008) was a major component of this overview, a postscript describing the outcome of the PBL report became necessary.

The aim of the PBL report was to conduct an investigation of the extent to which the IPCC in its summaries had presented existing scientific knowledge to the world of policymakers in a way that was supported by the underlying texts and scientific references (PBL, 2010, p. 5). The PBL report was initiated because of two reported errors in the IPCC Fourth Assessment Report. The first error concerned an erroneously high rate of melting of the Himalayan glaciers, and the second error concerned an erroneously high percentage of land area in the Netherlands lying below sea level.
Both errors were contained in the regional chapters of the IPCC Working Group II report. The PBL report investigated both the regional chapters of the IPCC Working Group II report and the Synthesis report.

The PBL report found that overall the summary conclusions of the IPCC were considered wellfounded and none were found to contain any significant errors (PBL, 2010, p. 9). The PBL report further concluded that, in some instances, foundations for the summary statements should have been made more transparent (p. 9). The PBL report resulted in a list of errata and corrections to the Working Group II's contribution to the IPCC Fourth Assessment Report, which can be found on the IPCC's website. As of June 26, 2010, none of the listed errata affect the citations made in this article from the Synthesis Report.

The PBL report further critiques the methodology of the IPCC in the Fourth Assessment Report. The IPCC methodology (which was agreed by its member governments) was to single out the most important negative impacts of climate change. Instead, the PBL report recommends that the full spectrum of regional impacts is summarized in the upcoming Fifth Assessment Report, including the uncertainties.

Despite these criticisms, it is important to note that the overall conclusion of the PBL report was that the Fourth Assessment Report was sound. In addition, the PBL report made clear that it did not question the IPCC conclusions that global warming since the middle of the 20th century is very likely to have been due to human influence on the global climate, as this conclusion was found by a previous review to be robust, even when taking into account peer-reviewed scientific literature expressing doubts on this relation (PBL, 2010, p. 12)

\section{REFERENCES}

Brander, L. M., Rehdanz, K., Tol, R. S. J., \& van Beukering, P. J. H. (2009). The economic impact of ocean acidification on coral reefs. Retrieved from
http://www.esri.ie/UserFiles/publications/2009 0218113337/WP282.pdf

Brown, D. A. (2010, January 31). A comprehensive ethical analysis of the Copenhagen Accord [Web log post]. Retrieved 


\section{from}

http://rockblogs.psu.edu/climate/2010/01/acomprehensive-ethical-analysis-of-thecopenhagen-accord.html?p=343

Bueno, R., Herzfeld, C., Stanton, E. A., \& Ackerman, F. (2008). The Caribbean and climate change: The costs of inaction. Retrieved from Stockholm Environmental Institute website: http://seius.org/Publications_PDF/SEICaribbeanAndClimateChange-08.pdf

Burke, L., \& Maidens, J. (2004). Reefs at risk in the Caribbean. Washington, DC: World Resources Institute. Retrieved from http://pdf.wri.org/reefs_caribbean_full.pdf

Caribbean Catastrophe Risk Insurance Facility. (2010). Enhancing the climate risk and adaptation fact base for the Caribbean: preliminary results of the ECA study. Grand Cayman, Cayman Islands: Author. Retrieved from http://www.ccrif.org/sites/default/files/publicat ions/ECABrochureFinalAugust182010.pdf

Den Elzen, M. G. J., Hof, A. F., Mendoza Beltran, M. A., Roelfsema, M., van Ruijven, B. J., van Vliet, J., \& Moltmann, S. (2010). Evaluation of the Copenhagen Accord: Chances and risks for the $2{ }^{\circ} \mathrm{C}$ climate goal (PBL Publication No. 500114018). Retrieved from Netherlands Environmental Assessment Agency (PBL) website:

http://www.rivm.nl/bibliotheek/rapporten/5001 14018.pdf

Dubash, N. K. (2009, December). Copenhagen: Climate of mistrust. Economic \& Political Weekly, 44(52), 8-11. Retrieved from http://www.cprindia.org/papersupload/126320 9675-Copenhagen.pdf

Fuller, C. (2010, March). Beyond Copenhagen. The Caribbean Climate, 1(1), 1-4. Retrieved from http://caribbeanclimate.bz/index.php?option=c om_docman\&task=doc_details\&gid=2\&Itemid $=3$

Guérin, E., \& Wemaere, M. (2009). The Copenhagen Accord: What happened? Is it a good deal? Who wins and who loses? What is next? Idées pour le débat, 8/9. Retrieved from
Institute for Sustainable Development and International Relations website: http://www.iddri.org/Publications/Collections/I dees-pour-ledebat/Id_082009_guerin_wemaere_accord_co penhague.pdf

Haites, E., Pantin, D., Attza, M., Bruce, J., \& MacKinnon, J. (2002). Assessment of the economic impact of climate change on CARICOM countries. Retrieved from Margaree Consultants website: http://www.margaree.ca/reports/ClimateChang eCARICOM.pdf

Hoegh-Guldberg, O., Mumby, P. J., Hooten, A. J., Steneck, R. S., Greenfield, P., Gomez, E., ... \& Matziolos, M. E. (2007). Coral reefs under rapid climate change and ocean acidification. Science, 318(5857), 1737-1742. doi:

10.1126/science.1152509

Hovi, J., Sprinz, D. F., \& Underdal, A. (2009). Implementing long-term climate policy: Time inconsistency, domestic politics, international anarchy. Global Environmental Politics, 9(3), 20-39.

Huq, S., Chandani, A., \& Anderson, S. (2009). After COP15, which way now for the most vulnerable countries? Outreach, Special post COP15 issue, 1-2. Retrieved from http://www.stakeholderforum.org/fileadmin/fil es/Outreach_issues_2009/OutreachFinalWrap Up.pdf

Intergovernmental Panel on Climate Change. (2008). Climate change 2007: Synthesis report. Geneva, Switzerland: Author. Retrieved from http://www.ipcc.ch/pdf/assessmentreport/ar4/syr/ar4_syr.pdf

Intergovernmental Panel on Climate Change. (2010, February 2). Statement on IPCC principles and procedures [Press release]. Retrieved from http://www.ipcc.ch/pdf/press/ipcc-statementprinciples-procedures-02-2010.pdf

Knutson, T. R., McBride, J. L., Chan, J., Emanuel, K., Holland, G., Landsea, C., ... \& Sugi, M. (2010). Tropical cyclones and climate change. Nature Geoscience, 3, 157-163. doi:10.1038/ngeo779 
Netherlands Environmental Assessment Agency. (2010, July 5). Assessing an IPCC assessment: An analysis of statements on projected regional impacts in the 2007 report. Retrieved from

http://www.pbl.nl/en/publications/2010/Assess ing-an-IPCC-assessment.-An-analysis-ofstatements-on-projected-regional-impacts-inthe-2007-report.html

Reilly, J., Paltser, S., Feltzer, B., Wang, X., Kicklighter, D., Melillo, J., ... \& Wang, C. (2007). Global economic effects of changes in crops, pasture, and forests due to changing climate, carbon dioxide, and ozone. Retrieved from Joint Program on Science and Policy of Global Change, Massachusetts Institute of Technology website http://web.mit.edu/globalchange/www/MITJP SPGC_Rpt149.pdf

Stern, N. (2006). The economics of climate change: The Stern review. Retrieved from http://webarchive.nationalarchives.gov.uk/+/ht tp://www.hmtreasury.gov.uk/stern_review_report.htm. (This is an archived website containing the prepublication pdfs of the report that was officially published as Stern, N. (2007). The economics of climate change: The Stern review. Cambridge, England: Cambridge University Press.

Tol, R. S. J. (2009). The economic effects of climate change. Journal of Economic Perspectives, 23(2), 29-51. doi: $10.1257 / 089533009788430652$

United Nations Economic Commission for Latin America and the Caribbean. (2006). Nutrition, gender and poverty in the Caribbean subregion (Document no. LC/CAR/L.105). Retrieved from http://www.eclac.cl/publicaciones/xml/2/2767 2/L.105.pdf

United Nations Environment Programme. (2009). Caribbean environment outlook. Retrieved from: http://www.unep.org/geo/pdfs/Caribbean_eo_f inal.pdf

United Nations Environment Programme. Regional Office for Latin America and the
Caribbean. (2008). Climate change in the Caribbean and the challenge of adaptation. Panama City, Panama: Author. Retrieved from: http://www.pnuma.org/raiz/Climate_Change_i n_the_Caribbean_Final_LOW20oct.pdf

United Nations Framework Convention of Climate Change. (1992). [Text of the convention] (Document no. FCCC/INFORMAL/84 GE.05-62220 (E) 200705). Retrieved from http://unfccc.int/resource/docs/convkp/conven g.pdf

United Nations Framework Convention on Climate Change. (2010, March 30). The Copenhagen Accord. Report of the Conference of the Parties on its fifteenth session, held in Copenhagen from 7 to 19 December 2009: Addendum. Part Two: Action taken by the Conference of the Parties at its fifteenth session (Document No. FCCC/CP/2009/11/Add.1). Retrieved from http://unfccc.int/resource/docs/2009/cop15/eng /11a01.pdf

United States Agency for International Development. Bureau for Latin America and the Caribbean. (2009). Latin America and the Caribbean: Selected economic and social data (Document No. PN-ADQ-200). Washington, DC: Author. Retrieved from http://pdf.usaid.gov/pdf_docs/PNADQ200.pdf

Vidal, J. (2009, December 10). Vulnerable nations at Copenhagen summit reject 2C target: Alliance of Small Island States say any deal that allows temperatures to rise by more than $1.5 \mathrm{C}$ is 'not negotiable'. The Guardian (UK). Retrieved from http://www.guardian.co.uk/environment/2009/ dec/10/copenhagen-climate-change 